\title{
FOR YOUR BOOKSHELVES ...
}

All figures given in dollars are in U.S. funds. Symbols listed are as follows: $C=$ cloth, $P=$ paper, $F=f l e x i c o v e r, H=$ hardcover.

NEW BOOKS

Anderson, O.L., O'Connell, R.J., Eyfe., W.S. and äbimova, E.A. (eds.) EVOLUTION OF THE EARTH. AGl, (1981), 300 p., \$19.00. Avalable from RGL, 2000 Flo
20009, U.S.A.

Arenal, R. CONTRIBUCIONES A LA PALEOBOTANICA DEL JURASICO DE MEXICO. (1981), 58 p. no price listed. Available from instituto de Geologica, Ciudad Universitaria, México 20 , D.F.

Bardossy, G. KARST BAUXITES. Elsevier, (1982), Vol. 14, Deveiopments in Economic Geology, $440 \mathrm{p} . \$ 83.00 / \mathrm{Df} 1.195 .00$. Available from Else vier, Scientific Publishimg Co., P.O. Box 211 , $1000 \mathrm{AE}$ Amsterdam, The Netherlands or E1scuier Nor th-Holland Inc., 52 Vanderbilt Ave., New York, NY 10017, U.S.A.

Berlin, G.L. EARTHQUAKES AND THE URBAN ENVIRONMENT: 3 volumes. Vol. 1: 224 p., 1980 , $\$ 63.95$ (inside U.S.); $\$ 73.95$ (outside U.S.\}. Refer to catalogue number 5173 QE. Vol. 2: $192 \mathrm{P}$.,
$1980, \$ 55.95$ (U.S.); $\$ 64.95$ (outside). $5174 \mathrm{QE}$. 1980, $\$ 55.95$ (U.S.); $\$ 64.95$ (outside). $\$ 174$ QE.
Vol. 3 : 288 p., $1980, \$ 78.95$ (U.S.); $\$ 88.95$ (outside). $5175 \mathrm{QE}$. Available from CRC Press Inc., 2000

NW 24 th St., Boca Raton, Florida 33431, U.S.A. PROPERTIES OF ROCKS, VOl 1: 416 P. 1982 $\$ 64.95$ (inside U.S.); $\$ 74.95$ (outside li.S. Catalogue number 02260E. Vol. 2: 368 p., 1982 , $\$ 59.95 / \$ 68.95$. Catalogue Number 0227QE. Available from CRC Press inc. (for address see above listing)

Carter, N.L., Friedman, W., Logan, J.M. and Sterns,
D.W. MECHANICAL BEHAVIOR OF CRUSTAL D.W. MECHANICAL BEHAVIOR OF CRUSTAL ROCKS. AGU, (1981), 336 p., $\$ 32.00$ (F). Avail-
able from AGU. (for address see Anderson listing) Coates, D.R. ENVIRONMENTAL GEOLOGY. Wiley, (1981), 731 p., no price listed. Available from
John Wiley \& Sons, Inc., 605 Third Ave., New York, New York 10158, L.S.A.

Costa, J.E. and Baker, Y.R. SURFICIAL GEOLOGY: BUILDING WITH THE EARTH. John Wiley (1981), $498 \mathrm{p.}$, no price listed. Avatlable from Wiley
(for address see above list ing)

Decker, R, and Decker, B. VOLCANOES. Freeman, (1981), 244 p., \$9.95. Available from W.H. Free man and Co., 660 Market St., San Francisco, California 94104 , U.S.A.

Dohr, G. APPLIED GEOPHY SICS. 2nd ed. of Geology and Fetroleum, Series Vol. 1, wiley, (1981), 231 p., $\$ 22.81$. Awallable

Ehiers, E.G. and Blatt, H. PETROLOGY: IGNEOUS, SEDIMENTARY AND METAMOR PHIC. Freeman, $(1982), 732 \mathrm{p} ., \$ 29.95(\mathrm{H})$. Available from Freeman (for address see Decker listing)

EnISt, W.G. THE GEOTECTONIC DEVELOPMENT OF CALIFORNIA. Vol. 1 in the Rubey Series. OF CALIFORNIA. Vol. 1 in the Rubey Series,
Prentice-Hall, $(1981), 706$ p. $\$ 35.95(\mathrm{C})$. Avalable Prentice-Hall, $(1981), 706$ p., $\$ 35.95$ (C). Avalable
from Prentice-Hall, Inc., Englewood Ciiffs, New Jersey 07632 , C.S.A.

Erast, W.G. and Morin, J.G. THE ENVIRONMENT OF THE DEEP SEA. Vol. 2 in the Rubey Series. Prentice-Hall, (1982), 400 p., \$35.95. Available

Fletcher, W.K. ANALYTICAL METHODS IN GEOCHEMICAL PROSPECTING. Elsevier, (1981), 256 p. $\$ 59.50 / \mathrm{Df1}$. 140.00. Available from Eise vier. (for address see Bardossy listing)

Frye, K. (ed.) THE ENCYCLOPEDIA OF MINERALOGY. Academic Press, (1981), $91 \geq$ p. $\$ 95.00$. Volume IVB in the Encyclopedia of Earth Sciences Series. Aval able from Academic Press [nc., MI] Fifth Avenue, New York, NY, 10003 , U.S.A.

Govett, G.J.S. ROCK GEOCHEMISTRY IN MINERAL EXPLORATION. EIsevier (1982), 356 p., no price listed. Available from Elsevier (for address see Bardossy listing).

Gupta, H.K. and Delany, F.M. (eds.) ZAGRosHINDU KUSH-HIMALAYSA-GEODYNAMIC EVOL UTION. $M G U(1981), 332 \mathrm{p} ., \$ 28.00$. A volume in the Geodvnamics Series. Available from AGt in the Geodynamics Series. Avait

Kröner, A. (ec.) PRECAMBrian Plate tectonics (Vol, 4 in the Development in Precambrian Geology series). Elsevier. (1981.780 D. \$185.25 (U.S.): Dil 380.00. Available from Elsevier (for address see Bardos sy listing).
Kulm, L.D., Dymond, J., Dasch, E.J., and Hussong, D.'. NAZCA PLATE: CRUSTÁL FORMATION AND ANDEAN CONVERGENCE. Cieological Socie ty of America Memoir $154(1981), \$ 18.00$ Available from Geologiral Society of Ainerica, Publication Sales Dept.
Colorado 80301 , U.S.A.

Lea therman, S.P. (ed.) OVERWASH PROCESSES Vol. 58 in the Paper in Geology Series. Academ ic Press, (1981), 400 p. $\$ 45.00$. Available from

Lloyd, J.W. (ed.) CASE STUDIES IN GROUNDWATER RESOURCES EVALUATION. Clarendon Press, (1981), $206 \mathrm{pu}, \$ 74.00$. Available from Clarendon Press, Oxford liniversity Press, 200
Ave., New York, NY 10016, U.S.A.

Mitchell, A.H.G. and Garson, M.S. MINERAL, DEPOSITS AND GLOBAL TECTONIC SETTINGS. Academic Press Geology Series, (1981), 440 p. Academic Press Geology Series,
$\$ 48.50$. Avalable from Acadenic Press. (for \$4.50. Available fron
address see listing)

Neumann, H-J., Paczynska-Lahme, B., and Severin, D. COMPOSITION AND PROPER TIES OF PETROLEUM. (1981), 137 p., \$17.58. Available from Wiley (for address Coates listing).

THE ORIGIN AND EVOLUTION OF THE EARTH'S CONTINENTAL CRUST. Royal Soriety, (1981), 303 p. U.K. 32.95 pounds; others 34.50 pounds (C). Available from the Royal Society, 6 Carn
House Terrace, London SW 1 Y 5 AG, U.K.)

Potter, F.E., Maynard, J.B, and Pryor, W.A. SEDlMENTARY OF SHALE: STUDY GUIDE AND REFERENCE SOURCE. Springer-Verlag (1980), 310 p., $\$ 29.80$. Available from Springer-Verlag Now York Inc., Dept. $\$ 3970,175$ Fifth Ave., New rork, NY 10010, U.S.A.

Richards, F.A. (ed.) COASTAL UPWELLING. AGU, (1981), $\$ 23.00$. Available from AGU (for address see Anderson listing).

Said, R. THE GEOLOGICAL EVOLUTION OF THE RIVER NILE. Springer-Verlag, (1981), $176 \mathrm{p}$. $\$ 59.00$. Available from Springer-Verlag (for address see above listing).

Skinner, B.J. (ed.) THE SOLAR SYSTEM AND ITS STRANGE OBJECTS. A volume in the serjes Earth and Its Inhabitants, Readings from American Scientist, Kaufman, (1982), 193 p., no price listed. Available from William Kautman, Inc., 95 First
St.. Los Altos. California 94022, L.S.A.

Sonnenfeld, P. (ed.) TETHYS: THE ANCESTAL MEDITERRANEAN. Vol. 53 in the Papers in Geology Series. Academic Press, (1981), 331
p., $\$ 140.00$. Available from Academic Press (ior address see Frye listing)

Sweeting: M.M. (ed.) KARST GEOMORPHOLOGY. Vol. 59 in the Papers in Ceology Series. Academi Press (1981), 448 p., $\$ 56.00$. Available from Academir Press (for address see Frye listing).

Tankard, A.J., Jackson, M.P.A., Eriksson, K.A.. Hobday, D.K., Hunter, D.R. and Minter, W.E.L. CRUSTAL EVOLUTION OF SOUTHERN AFRICA: 3.8 BILLION YEARS OF EAR TH HISTORY. Springe Verlag, (1981), $480 \mathrm{p} ., \$ 45.80$ (F). Available from

Teichert, C., Lu, L., and Pei-ji, C. PALEONTOLOGY

IN CHINA 1979. (1981), 270 p., \$44.00. Available IN CHINA 1979. (1981), $270 \mathrm{p}$., $\$ 44.00$. Avaitable Sales, P.O. Box 9140 , Bowider, Colorado 80301 , Sales, P.O
U.S.A.

Titley, S.R. (ed.) ADVANCES IN GEOLOGY OF THE PORPHYRY COPPER DEPOSITS. 2nd ed. (1982), 580 p., $\$ 35.00$ (C). Available from Univer sity of Arizona Press, Box 3698, Tucson, Arizona 85772 , U.S.A.

Voipio, A. (ed.) THE BALTIC SEA. No. 30 in the Oceanography Series. Elsevier, (1982), 418 p. $\$ 129.00$. Avallable irom Elsevier (for address see Bardossy listing).

Williams, G.E. (ed.) MEGACYCLES: LONG-TERM EPISODICITY IN EARTH AND PLANETARY HISTORY. Vol. 57 in Papers in Geology Series. HISTORY. Vol. 57 in Papers in Geology Series.
Academic Pres5 (1981), 434 p., \$49.00. Available Academic Press (1981), 434 P., \$49.00. Available
from Academic Press (for address see Frye listing) PROCEEDINGS OF SYMPOSIA

ALUMINA PRODUCTION UNTIL 2000. Proceedings of a symposium organized jointly by ICSOBA,
OMBKE and HUNGALU in Tihany, Hungary, Oct- ober 6-9, 1981. In English, \$40.00. Available from OMBKE, Rudapest $p$ f.; $240, H-1368$, Hungary.

Fayers, F.J. (ed.) ENHANCED OIL RECOVERY. Elsevier, (1981), v. 13, Developments in Petroleum Science, Proceedings of the 3rd European Sympos $\$ 72.25 / \mathrm{DFI}$ 170.00. Avaitable from EI596 p., $\$ 72.25$ (forl.

Ferrusquia-Villafrance. I. (ed.) CONEXIONES TERRESTRES ENTRE NOTRE Y SUDAMERICA. Proceedings of an interdisciplinary symposium. Mexico, 1978. Instituto de Geologia, (1981), $329 \mathrm{p}, \$ 10.00$. Available from Instituto de Creologia, Universidad Nacional Autonoma de México. México, D.F.

Rose, A.W. and Gunlach, H. GEOCHEMICAL EXPLO RATION, 1980, Proceedings of the 8 th internatIona! Geochemical Explorarion symposium held
in Hannover, F.R.G., April 10-15, 1980. Elsevier, 1981, 724 p., \$153.25/Df 1. 360.00. Avajlable from Elsevier (for address see Bardossy listing).

Weinstock, H. and Overton, Jr., W.C. SQUID APPLICATIONS TO GEOPHYSICS, 26 papers presented at workshop on SQLID Applications to Geophysics held at the Los Alamos Scientific laboratory, June. 1980, SEG members $\$ 20.00$; others $\$ 25.00$ plus $\$ 2.00$ postage outside U.S.A. Aval able from 3098, Tulsa, Oklahoma 74101, U.5.A.

\section{NEW JOURNALS}

QUATERNARY SCIENCE REVIEW. Quarterly international multidisciplinary review journal. Editor: D.Q. Bowen. Subseription: $\$ 70.00$. Pergamon,
Press, Headington Hill Hall, Oxford ox3 OBw, Press,

TECTONICS. Bimonthly publication, first issue February, 1982. Central theme is the mechanical and thermal evolution of the lithospheric crust and mantle. Publishers: American Geophysical Union and European Geophysical Society. Subsriptions: $\$ 20.000$ AGL/EGS members. Others, contact AGU, 2000 Florida Ave., NW, Washington, D.C. 20009 , U.S.A.

MISCELLANEOUS

Bogoch, R. (ed.) CURRENT RESEARCH 1980, 139 p., 55.00. Available from Geological Survey of Israel,
Library, 30 Malkhei Yisrael St.. Jerusalem 95 Library, 30
501 . Israel.

Constantinou, G. ANNUAL REPORT OF THE GEOLOGICAL SURVEY DEPAR TMENT FOR THE YEAR 1980, October, 1981, 61 p.. no price list. Available from Ministry of Agriculture and Na

GEODETIC MONITORING OF TECTONIC DEFORMATION - TOWARD A STRATEGY. Panel on Crustal Movement heasurements, Committee
on Geodesy. Academic Press (1981), 119 p., $\$ 2.00$. Available from Committee on Geadesy, $210 \mathrm{~L}$ Constitution Avenue, Washington, D.C. 2041S, U.S.A.

Mitchell, I. WATER RESOURCES IN BOLIVIA. (Bibliography). GEOBOL-ACID (1981), 133 p., $\$ 8.00$. Available in Spanish from Academlc NacPaz, Boljvia.

VASA Geodynamics Program, ANNUAL REPORT FOR 1980, October, 1981.80 p., NASA Technica Memo 84010. NASA, Technical Intormation Service, Springfield, Virginia 22161 , U.S.A. IGCP PUBLICATIONS

LATERISATION PROCESSES. Proceedings of the International Seminar on Laterization Processes, IGCP Project 129, Trivandrum, India, December 11-14, 1979. Available from Oxford (1981), 66
Janpath, BH Publishing Co., New Dethi, Bombay, Calcutta.

Sibrava, V. and Shotton, F.W. QUATERNARY GLACIATIONS IN THE NORTHERN HEMISPHERE. Project No. 73-1-24 Report No. 6 on the session in Ostrava, Czechoslovakia, August 16-25, 1979.
Ceological Survey (Prague, 1981 ), Malostranské nam. 19, 11821 Praha 1, Czechoslovakia.

IUGS/AFFILIATES PUBLICATIONS

SOUTHEAST ASIA GEOSCIENCES Newsletter of the SE Asia Regional Network of Geosciences and AGID, Vol. 4, No. 2 (December, 1981), 32 p. Chiang Mai University, Chiang Mai, Thajland. 
